\title{
Re-engineering human capital in the creative dimension
}

\author{
T.I. Kruzhkova*, O.A. Ruschitskaya, O.E. Ruschitskaya, and E.M. Kot \\ Ural State Agrarian University Ekaterinburg, 42 Karl Liebknecht St., Ekaterinburg, Russia
}

\begin{abstract}
The paper deals with the problem of forming the system of creative management of human resources (personnel) of enterprise and their transformation into human capital. It analyzes the existing approaches and gives the evaluation of the current situation in solving this problem. The key questions of forming the creative type of human capital management: convergence and convergence of social, cultural, intellectual and physiological capitals are revealed. Ways of reengineering human capital under conditions of growing macroeconomic and political instability, uncertainty and risks are shown. Particular attention is drawn to the possibilities of competence-based and the need for differentiated approaches in the training of professionals under conditions of growing macroeconomic instability and uncertainty.
\end{abstract}

\section{Introduction}

Under the conditions of steadily growing economic instability and uncertainty associated with the development of unfair competition, the consequences of the Covid-19 pandemic, the sanctions policy against our country by the Western powers, and various types of price and customs wars, the human capacity for creative problem-solving, for rapid response to the changing market environment is becoming increasingly important.

This ability is a special form of creativity based on a high (developed) intellect. The current "era of business with the speed of thinking" [1] is associated with the transition from the previous model of "lean production" to the new model of "responsive production" (R.Suri) [2], which makes the creativity factor a key one in this movement.

The aim of the study is to analysis the possibilities for the creation and development of creative human capital management in the context of macroeconomic instability and uncertainty.

\section{Methodology and methods}

This paper utilises the methodological framework of analyzing the creative management of human capital in the context of macroeconomic instability. This research is based on the

\footnotetext{
${ }^{*}$ Corresponding author: rustale@yandex.ru
} 
synergetic principle of studying the reengineering of human capital. The methods for the study also included the study, analysis, synthesis and synthesis of philosophical and economic literature.

\section{Results of the study}

Intellectual development in recent decades has fostered the emergence of new technologies in the field of human resource management (HRM) of enterprises. These include crowdfunding, crowdsourcing, crowdfunding, the use of workforce reliability programmes (WSPs), foresight programmes, blockchain technology, etc.

However, despite these technological innovations, the effectiveness of human resource management is still unsatisfactory in many respects. This includes frequent conflicts between management and employees of enterprises (organizations), staff turnover, inefficient personnel placement, labor contracting practices (so-called 'effective contracts'), and employee appraisal. The typical manifestations of such inefficiency are arbitrariness, voluntarism, bureaucratism and formalism in the management system, which indicates an internal growing dichotomy between managers and executives, a growing social alienation, a deepening gap in the interests of the enterprise and its employees. The result is a growing number of bankruptcies. At the end of 2020, this figure rose (relative to 2019) by $70 \%$. There were 81 bankruptcies for every 100,000 people in the Russian Federation in 2020, in 2019. - 47 and in 2018. - 30 [15]. Staff turnover in the Russian Federation also increased by $10 \%$ in relation to 2019 and amounted to $23.8 \%$. If we talk about the median value of the staff turnover rate, it increased even more significantly, up to $43.8 \%$ [16].

These indicators only prove the necessity of reengineering in the sphere of human capital management. There is nothing new in the necessity of these or those reengineering models. This idea in economic science was formulated by T. Davenport, T. Robert, M. Hammer, J. Champy and Short, who presented reengineering of any business processes as a way to radically renew companies' activities in rapidly changing conditions [17].

But here there is an ideological problem rather than an economic one - the problem of cooperation. It is obvious that our society still lives not in the format of such cooperation, but in the paradigm of social competition. And although competition serves the good only in a moral society in which spiritual values dominate over material values, in which the level of culture, education and upbringing is high, nevertheless, it is often simply blindly extrapolated to the contemporary Russian society which is in a systemic existential crisis.

Unfortunately, in recent years, cooperation between administration and staff has been devalued by the system of bureaucratic management in most domestic enterprises. Describing the current bureaucratic management system, E. Fromm noted: "Bureaucratism can be described as a method in which: a) people are treated like things; b) things are considered only in terms of quantity rather than quality, which simplifies and cheapens their accounting and control" [18, p.281].

But in the context of growing instability, uncertainty and high risks, fundamentally different models are needed - participative, project-based, business-process, venture-based. The specific values of these models in the Russian economy are minimal. And, for example, in the USA, the same venture companies now account for $30 \%$, while in Russia they account for less than $3 \%$. Moreover, they generate profits several times higher than those of conventional enterprises [19].

The problem is that most Russian enterprises and organizations have not yet created an atmosphere of creative cooperation. 
And this circumstance is one of the fundamental reasons for the emerging situation of macroeconomic instability and turbulence, uncertainty and high risks.

\section{Discussions and debates}

There are different perceptions of creativity [3]. However, the creative approach to human capital management is constrained in many respects by the conservative views of scientists about its proper use, about the reasons for its low efficiency and traditional ideas about the main directions of its development.

Another important circumstance is the lack of clear and generally accepted ideas in economic science about the essence and correlation of such concepts as "human capital", "social capital", "intellectual capital", "organizational capital", "cultural capital", "physiological capital", etc.

However, with all the variety of definitions of human capital, not all researchers consider this concept to be generalizable. In some studies human capital is a particular element in relation to the concept of "intellectual capital", which also includes organizational capital, relationship capital, emotional capital, cognitive capital, relationship (client) capital [4, p. 87]. But there are publications, in which the opposite is true: social capital, relational (client) capital and organizational capital are considered as elements of human capital structure $[5 ; 6]$.

The most important directions of increasing efficiency in the functioning of human capital usually include increasing the volume of working time, increasing the workload of employees, increasing the intensity of their work, increasing the consistency of their actions and improving the quality of work performed [7, p. 641].

In foreign literature there is a slightly different view of this problem. Thus, developing the model of creative management - "the ring of renewal" - R. Waterman as far back as the mid 80 s of the last century named culture, awareness, communication, motivation, planning (including crisis situations) and flexible control as key factors in the ability of enterprises (corporations) to function effectively. [8, c.74-78].

In the context of our study, the ideas formulated in the book by D. Kahneman and A. Tversky "Theory of Perspectives: The Study of Decision Making under Conditions of Risk" (1979), in which the authors were among the first to formulate the idea of expected utility, are of particular interest. In essence, they were talking about the economy of the future, that human expectations, and not the length of the working day or the control system, are the decisive factor in the development of the economy.

Modern neo-behaviorists have significantly revised the starting points of the nature of human behavior towards fetishizing the idea of rationality [9, p.354-356]. Some authors even note contradictions between real and rational behavior of employees $[10 ; 11 ; 12]$. As the basic principles of economic rationalism, they name the following: "a person chooses", "a rational person thinks in terms of marginal changes", "trade is carried out for the benefit of everyone", "living standards of the population are determined by the country's ability to produce goods and services", etc. [12, c.29-44].

Even the named principles are enough to understand that their rational understanding does not correspond to reality. Since the named principles assume their universal significance, all their defects become clear. The modern man, who finds himself in the system of bureaucratic management, is not free [14]. 


\section{Conclusion}

The new social reality is changing rapidly. And in this situation it is necessary to keep in mind not only general (macroeconomic), but also those specific personal limitations that hinder creativity. At the end of the last century British researchers M. Woodcock and D. Francis identified a number of such constraints and, at the same time, seventeen signs of creativity in leadership [20, pp.139-142, 152-153]. There are other works that investigate the conditions for realisation of creative (creative) potential [214,22;23]. This includes the use of human capital in different sectors of the economy [24;25;26].

At the same time, human resource management and management of creative employees imply significantly different approaches to solving the problems of managerial reengineering in these areas. The employee as an object of management and the personnel (team) as an object of management are two big differences. The first deals with the individual nature of activity, while the second deals with the social relations between different workers. In other words, the social capital associated with the establishment and maintenance of links with other economic agents.

Today we are still in the paradigm of individualistic, personalized personnel management, which is connected with the destruction of the old ideology of collectivism (collectivity). Instead of the work collective, which was the object of management in Soviet times, corporate management manages specific people (personnel). This circumstance makes it difficult to form social capital as a generalized form of human capital.

Social capital is a set of relations, as a result of which people perform their professional duties in good faith and without coercion (sanctions) [27]. The expectations in society about this socially responsible attitude of employees to their professional duties is expressed in the concept of trust. "Trust is a kind of lubricant of the social mechanism. It is extremely effective" [28, p.254].

In many modern enterprises the threshold of trust is extremely low, and the conflict between the administration (management) and personnel (employees) exists either in latent, hidden form, or constantly breaks out in various forms of social opposition (deviant and delinquent behavior).

It should be remembered that "human capital is not sold, not exchanged and not transferred from one person to another", which makes it a unique economic resource, which is easy to lose or destroy, and requires a lot of time and effort to restore or create [29, p.129]. The situation with the loss of trust is not saved even by the attempts of the management of many companies to introduce new automation systems or artificial intelligence in enterprises [30]. New technological methodologies of reengineering (SASD, SADT, IDEF), which, although used [31], are still ineffective due to the fact that they are hampered by the bureaucratic type of management culture established in enterprises.

One manifestation of this type of bureaucratic management culture in enterprises is a rather narrow focus on the development of employees' skills and competences. Today, this is a generally accepted strategy for human resource development. It is a kind of 'creed' in the education system. However, it is not employers themselves who formulate 'required' competences, but officials at various levels. Therefore, in this case we should hardly speak about human capital, as knowledge, which is received by future employees, does not bring income by itself, for that they need to be able to capitalize. And this, by and large, is not taught in modern higher education, with few exceptions. Either universities do not have the necessary material and technical basis or they lack highly professional teachers. Or something else.

Some big companies even try to go their own way and establish their own businesses, like, for example, the Ural Mining and Metallurgical Company, which started its own 
corporate university in Verkhnyaya Pyshma, a town near Ekaterinburg. Or Severstal, which set up its own corporate university in Cherepovets. There are about 300 such universities in the Russian Federation today. However, this way of creating the human capital required by the employer is not suitable for everyone; only large, successful companies can afford it. And this way should hardly be considered as an alternative to the system of state education.

Accordingly, two main vectors of human capital reengineering can be outlined at the stage of its formation in the system of state and corporate education: 1) restructuring of knowledge necessary for the efficient operation of an individual and a company; 2) formation of a mechanism for the actualization (capitalization) of knowledge in the work process (business process).

To understand the complexity of the implementation of these areas, it should be borne in mind that human capital is by no means limited to intellectual capital (the sum of knowledge). It also includes:

- cultural capital (a person's system of values);

- Intellectual capital (knowledge, skills, abilities)

-physiological capital (age, health, physiological abilities)

-social capital (developed social ties, the ability to build communications);

- symbolic capital (rating, status, authority of the employee);

- psychological capital (psychological type of the person, his psychological characteristics which could be of use to him).

The conversion and convergence of these components of human capital is precisely the subject of re-engineering. Here, integrated and differentiated approaches to the assessment and design of human capital formation processes are necessary at the same time.

Trying to reveal the process of human capital reproduction in the framework of the competence approach, some researchers pay attention to the mismatch between the skills of an employee and the requirements to his/her skills on the part of enterprises (skill mismatch) [32, p. 10]. Or the discrepancy between the knowledge acquired in the process of education and the knowledge required by specific enterprises, because "depending on the priorities in the activities of the organization, priorities in knowledge are also set" [33, 30]. [33, c.30]. Indeed, often employers "have to wait for employees to acquire organizationspecific skills - to enter the business, to master the technological process, to establish relationships in the team" [29, p.303]. Similar problems are noted abroad [34].

At times, the new reengineering paradigm in the context of macroeconomic instability and uncertainty is proposed to be implemented "from scratch" by eliminating all operations and activities that are not related to the price formation of a product or service [35-38]. However, this radical version leaves human capital itself outside the scope of reengineering, as it represents only a new version of technological determinism.

Therefore, the issues of including human capital in the reengineering practice in the context of development of creative abilities of the enterprise employee require further scientific development (in particular, such areas as synectics, eutagogics, etc.).

The development and practical application of creative abilities of business entities through the development of their cultural, intellectual, physiological and social capital (as the most important components of human capital in general) and organizational support, by means of social partnership and methods of labor self-government should be inventoried and directed in a constructive direction.

\section{References}

1. B. Gates, Business at the Speed of Thought 480 (Moscow, Eksmo, 2007) 
2. D.A. Markov, N.A. Markova, Bulletin of Perm Research Polytechnic University, 2, 181-192 (2016)

3. V.V. Moroz, Vestnik of Orenburg State University, 12 (200), 35-41 (2016)

4. P.A. Novgorodov, Proceedings of the Ural State University of Economics, 20(1), 78-94 (2019)

5. V.V. Klochkov, Human capital and its development, Economic theory. Transforming Economy 417 (Moscow, Unity University, 2008)

6. A.F. Lysenkov, Management in Russia and abroad, 6, 3-11 (2009)

7. O.S. Cheremnykh, S.V. Cheremnykh, Strategic Corporate Reengineering: ProcessValue Approach to Business Management, 736 (Moscow, Finance and Statistics, 2005)

8. R. Waterman, The Renewal Factor. How the Best Companies Remain Competitive, 368 (Moscow, Progress, 1988)

9. J. Trout, S. Rivkin, Differentiate or die! Survival in the Age of Killer Competition, 224 (Saint Peterburg, Peter, 2003)

10. R. Thaler, The New Behavioural Economics. Why people break the rules of traditional economics 384 (Moscow, Eksmo, 2018)

11. M. Hunt, History of psychology, 863 (Moscow, 2009)

12. K.L. Bartels, Theory and Practice of Social Development, 1, 15-17 (2012)

13. A.A. Biryukova, Economics and Management: Problems, Solutions, 4, 190-195 (2014)

14. R. Schweri, Rational choice theory: an analytical review, URL:https://www.jour.fnisc.ru/upload/journals/1/articles/161/submission/copyedit/161 -302-1-CE.pdf

15. G.N. Mankew, Principles of economics, 784 (Saint Peterburg, Peter, 1999)

16. V.A. Niskanen, Welfare economics and public choice, 4, 477-495 (2004)

17. Finamarket, News, URL: http://www.finmarket.ru/news/5392491

18. HR in Russian, Staff turnover at Russian enterprises is growing, URL: https:/hrelearning.ru/tekuchest-kadrov-na-rossijskih-predprijatijah-rastet/

19. O. Mordkovich Reengineering of business processes, URL: https://www.osp .ru/cio/1998/06/171237

20. E. Fromm, To have or to be, 314 (MOSCOW, AST, 2011)

21. Venture Capital Business in Russia, URL: http://solev.ru/ru/informatsiya/analiticheskie-stati/2641-venchurnyj-biznes-v-ossii.html

22. M. Woodcock, D. Francis, The Liberated Manager, 320 (Moscow, Delo, 1991)

23. P.V. Zhuravlev, Human Resource Management: Experience of Industrialized Countries, 512 (Moscow, Examen, 2002)

24. M. Armstrong, S. Taylor, The Practice of Human Resource Management, 1040 (M., Jupiter, 2018)

25. H.T. Graham, R. Bennett, Human resource management, 600 (Moscow, Unity-Dana, 2003)

26. S.G. Golovina, L.N. Smirnova, I.N. Mikolaichik, Human capital in the socio-economic development of rural areas: a regional aspect 366 (Yekaterinburg, Ural State Agrarian University Press, 2020)

27. A.L. Kobleva, Human capital development in education, 154 (M., Yurait, 2020) 
28. N.F. Chebotarev, Innovation Policy and Human Capital in the Oil and Gas Industry of Russia's Fuel and Energy Complex, 184 (Moscow, Prospect, 2018)

29. J. Coleman, Social Science and Modernity, 3, 122-139 (2001)

30. F. Fukuyama, Trust. Social Virtues and the Path to Prosperity, 730 (Moscow, AST, 2004)

31. V.V. Radaev, Economic Sociology 603 (Moscow, GU Higher school of economics, 2005)

32. R. Josuthasan, J. Boudreau, Reengineering Business. How to Effectively Implement Automation and Artificial Intelligence, 280 (Moscow, Alpina Publisher, 2019)

33. M. Halmer, J. Champy, Reengineering the corporation. Manifesto for a business revolution, 287 (M., Mann, Ivanov \& Farber, 2009)

34. O.V. Shulaeva, Economic Sciences, 5 (126), 7-11 (2015)

35. V.M. Taroyan, Economics, 2(123), 29 - 42 (2015)

36. F. Green, Skills and skilled work: An economic and social analysis, 240 (Oxford, 2013)

37. S.D. Mezer, M.S. Semeykina, A.K. Tonian, International Research Journal, URL: https//research-journal.org/economical/sovremennye-podxody-kopredeleniyureinzhiniriga/.

38. K.P. Stozhko, D.K. Stozhko, Agrarian Bulletin of the Urals, 10(201), 73-83 (2020) DOI: 10.32417/1997-4868-2020-201-10-73-83 (In Russian) 